\title{
POTENSI DAN PENGEMASAN PAKET EKOWISATA DI KABUPATEN BERAU PROVINSI KALIMANTAN TIMUR
}

\author{
Aji Muhammad Fariz Devani ${ }^{1}$, IP. Sudana ${ }^{2}$, N.G.A.S. Dewi ${ }^{3}$ \\ Email:ajimfariz10@yahoo.com¹, sudanaputu@yahoo.com², susrami_ipw@unud.ac.id ${ }^{3}$ \\ ${ }^{1,2,3}$ Program Studi Sarjana Industri Perjalanan Wisata, Fakultas Pariwisata, Universitas Udayana
}

\begin{abstract}
This research was conducted to determine the potential of ecotourism in Berau Regency, East Kalimantan Province so that it can be packaged into an ecotourism package that covers the whole area of Berau Regency starting from the urban zone, the inland zone and the water zone. This research was conducted in Berau Regency because Berau Regency has 159 tourist attractions and also its location is close to the location of the new capital. The ecotourism package packaging made in this study is based on the lack of variety of products and tour packages circulating in Berau Regency so that this research is expected to add variety as well as introduce new potentials that can be found in Berau Regency. Data collection techniques used in this study are in-depth interviews, observation, documentation and literature study. After conducting research in Berau Regency, there are 17 ecotourism potentials which can be packaged into 4 kinds of ecotourism packages, with details of three full-day ecotourism packages and one 2-day 1 night ecotourism package and the ecotourism package itinerary in this study is made in the form of descriptions, tables and graphs as well as the type of ecotourism package in this study is ready made tour. The titles of the ecotourism packages in this study are (1) Berau Culture and City Tour, (2) Berau Mangrove and Sangalaki Island Tour, (3) Orangutan University and Merabu Forest Tour, (4) Mirror Lake and Whale Shark Tour
\end{abstract}

\begin{abstract}
Abstrak: Penelitian ini dilakukan untuk mengetahui potensi-potensi ekowisata yang ada di Kabupaten Berau, Provinsi Kalimantan Timur sehingga dapat dikemas menjadi sebuah paket ekowisata yang mencangkup keseleruhan wilayah Kabupaten Berau mulai dari zona perkotaan, zona pedalaman dan zona perairan. Adapun penelitian ini dilakukan di Kabupaten Berau dikarenakan Kabupaten Berau memiliki 159 daya tarik wisata dan juga lokasinya dekat dengan lokasi ibukota yang baru. Adapun pengemasan paket ekowisata yang dibuat dalam penelitian ini di latarbelakangi oleh kurangnya variasi produk dan paket wisata yang beredar di Kabupaten Berau sehingga penelitian ini diharapkan dapat menambah variasi sekaligus mengenalkan potensi yang baru yang dapat ditemui di Kabupaten Berau. Teknik pengumpulan data yang dilakukan dalam penelitian ini adalah wawancara mendalam, observasi, dokumentasi dan studi pustaka. Setelah melakukan penelitian di Kabupaten Berau, terdapat 17 potensi ekowisata yang dapat di kemas menjadi 4 macam paket ekowisata dengan rincian 3 paket ekowisata fullday dan 1 paket ekowisata 2 hari 1 malam dan itinerary paket ekowisata dalam penelitian ini dibuat dalam bentuk uraian, tabel dan grafik serta jenis paket ekowisata dalam penelitian ini adalah ready made tour. Adapun judul paket ekowisata dalam penelitian ini adalah (1) Berau Culture and City Tour, (2) Berau Mangrove and Sangalaki Island Tour, (3) Orangutan University dan Merabu Forest Tour, (4) Mirror Lake and Whale Shark Tour
\end{abstract}

Keywords: ecotourism, tourism potential, tour package. 


\section{PENDAHULUAN}

Pulau Kalimantan adalah pulau terbesar kedua di Indonesia setelah Pulau Papua. Pulau Kalimantan sering disebut juga sebagai "Paruparu Dunia" karena Pulau Kalimantan memiliki banyak sekali hutan lebat yang terdiri dari pohon dan tumbuhan hijau yang tersebar diseluruh Pulau Kalima ntan. Industri terus digali dan paling diminati di Pulau Kalimantan adalah batu bara dan kelapa sawit. Karena memiliki wilayah yang luas, Pulau Kalimantan di bagi menjadi beberapa wilayah, yaitu Kalimantan Barat, Kalimantan Utara, Kalimantan Selatan, Kalimantan Timur dan Kalimantan Tengah. Provinsi yang paling maju dan memiliki banyak daya tarik wisatanya di Pulau Kalimantan adalah Kalimantan Timur.

Provinsi Kalimantan Timur memiliki banyak hutan yang hijau, industri perkotaan di wilayah Kalimantan Timur juga sudah maju dan ini di barengi oleh banyaknya objek pariwisata yang ada di kota-kota Kalimantan Timur yaitu Samarinda, Balikpapan, Kutai Kartanegara, Bontang, dan juga Berau. Kabupaten yang memiliki objek dan daya tarik pariwisata yang banyak dan unik di wilayah Provinsi Kalimantan Timur ialah Kabupaten Berau. Kabupaten Berau terletak tepat di tengah-tengah dari Provinsi Kalimantan Timur dan sangat dekat dengan kota yang sedang maju di Kalimantan Timur, yaitu Samarinda dan Balikpapan. Kabupaten Berau mempunyai pariwisata alam yang cukup melimpah seperti Pulau Derawan, Labuan Cermin, Pulau Kakaban.

Dilansir dari (www.detik.com,2020) dalam artikel yang berjudul "Resmi, Jokowi Pindahkan Ibu Kota ke Pulau Kalimatan" yang di rilis pada tanggal 27 Agustus 2019, Presiden Terpilih Republik Indonesia, Joko Widodo menggelar konfersi pers dan telah resmi mengumumkan bahwa ibu kota negara akan dipindah yang semula di DKI Jakarta menuju Pulau Kalimantan, tepatnya Provinsi Kalimantan Timur. Adapun lokasi ibu kota negara yang baru adalah keseluruhan wilayah Kabupaten Penajam Paser Utara serta juga sebagian wilayah Kabupaten Kutai Kartanegara. Pemindahan ibukota ini di harapkan bisa menambah peningkatan jumlah wisatawan yang berkunjung ke Kabupaten Berau, karena lokasi Berau yang sangat dekat dengan Kabupaten Penajam dan Kutai Kartanegara

Dengan luas wilayah yang dimiliki oleh Kabupaten Berau, terdapat berbagai macam daya tarik wisata yang tersebar di seluruh daratan maupun laut dari Kabupaten Berau tersebut, hal ini tentu saja menarik minat wisatawan domestik dan juga wisatawan mancanegara untuk berkunjung ke Kabupaten Berau. Dalam beberapa tahun terakhir kunjungan wisatawan ke Kabupaten Berau terus meningkat dan setiap tahunnya peningkatan selalu signifikan antara wisatawan asing maupun wisatawan domestik.

Namun terdapat sedikit hambatan, yaitu tidak adanya produk wisata yang unik dan dapat menarik minat wisatawan untuk kembali ke Kabupaten Berau. Menurut artikel yang dilansir di situs (www.bisniswisata.com,2020) kebanyakan wisatawan hanya berkunjung sekali saja sehingga jarang dari wisatawan melakukan repeater ke Kabupaten Berau. Produk wisata dapat berupa voucher hotel, voucher makanan, voucher belanja, penawaran menarik dari daya tarik wisata, maupun juga paket wisata yang menarik.

Untuk dapat menarik wisatawan berkunjung ke Kabupaten Berau, cara yang bisa di usahakan agar dapat meningkatkan kunjungan wisatawan menuju Kabupaten Berau salah satunya adalah dengan membuat paket wisata yang unik, apalagi potensi dan pilihan berwisata di Kabupaten Berau sangat beragam dan memiliki keindahan serta keunikan sendiri yang tentunya tidak dimiliki oleh daerah lain sebagai contohnya flora yang dapat dijadikan sebagai objek wisata dan tentunya daerah lain tidak punya adalah Wisata Buah Labanan Lai, Kampus Orangutan dan Kampung Budaya Bena Baru.

Menurut Geva dan Goldman (1991) Paket wisata adalah komponen utama dari industri pariwisata, sebagai faktor penentu agar untuk wisatawan mendapatkan kepuasan saat mengunjungi suatu daya tarik wisata. Apabila paket wisata yang ditawarkan biro perjalanan wisata lebih menarik dan variatif, tentu saja wisatawan akan lebih senang,

Dalam penelitian ini, membuat paket wisata tidak hanya untuk jangka pendek 
semata, tetapi juga memikirkan jangka panjang dan masa depan serta bagaimana pariwisata di Kabupaten Berau tetap mengimplementasikan sustainable tourism agar tidak hanya meningkatkan pendapatan daerah, tetapi juga memikirkan kesejahteraan masyarakat lokal, tetap menjaga dan melestertarikan budaya serta menjaga kebersihan dan kelestarian lingkungan yang ada di Kabupaten Berau.

Menurut Fennel (1993) dalam buku Arida (2015), salah satu cara mengimplenetasikan pariwisata berkelanjutan adalah melalui ekowisata, maka paket wisata yang cocok untuk di buat dan dipasarkan di Kabupaten Berau adalah paket ekowisata yang ramah lingkungan dan yang mengajak wisatawan untuk menikmati sekaligus ikut terlibat dalam menjaga kelestarian alam itu sendiri agar Provinsi Kalimantan Timur terutama Kabupaten Berau dapat mencapai Pariwisata Berkelanjutan, maka paket wisata yang dibuat dalam penelitian ini haruslah dikemas dengan ramah lingkungan dan lebih melibatkan wisatawan untuk melakukan kegiatan wisata yang dekat dengan lingkungan, selain mendapatkan kepuasan, wisatawan juga mendapatkan ilmu dan pengalaman yang menyenangkan sehingga dapat di bagikan kepada sanak, saudara maupun keluarga ketika sampai di tempat asal.

\section{METODE PENELITIAN}

Adapun tinjauan konsep yang digunakan dalam penelitian ini adalah tinjauan konsep tentang pariwisata A.J. Burkat (2006), tinjauan konsep tentang potensi wisata Pendit (2003), tinjauan konsep tentang daya tarik wisata Yoeti (1996), tinjauan konsep tentang produk wisata A.J. Mulyadi (2009), tinjauan konsep tentang ekowisata Fandeli (2000), dan tinjauan konsep tentang paket wisata Yoeti (2001).

Adapun lokasi penelitian ini dilakukan di Kabupaten Berau, Provinsi Kalimantan Timur, sementara teknik pengumpulan data dalam penelitian ini dilakukan dengan cara observasi, wawancara mendalam, dokumentasi dan studi pustaka. Adapun dalam menentukan informan dalam penelitian ini, terdapat dua jenis informan yaitu informan pangkal dan informan kunci dan teknik analisis data yang digunakan dalam penelitian ini adalah teknik analisis data deskripif kualitatif.

\section{HASIL DAN PEMBAHASAN \\ Gambaran Umum Kabupaten Berau Provinsi Kalimantan Timur}

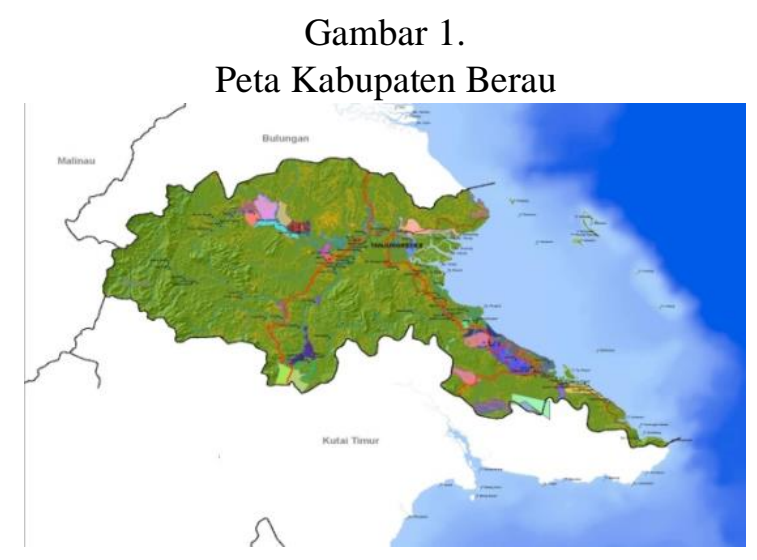

Sumber: Google Maps

Lokasi penelitian ini akan dilakukan di Kabupaten Berau Provinsi Kalimantan Timur. Kabupaten Berau sendiri mempunyai 13 kecamatan dan 102 desa. Pada tahun 2018, jumlah penduduknya mencapai 218.254 jiwa, sementara Kabupaten Berau memiliki luas wilayah 22.120,00 $\mathrm{km}^{2}$ dengan persebaran penduduk 11 jiwa/km.Pemilihan lokasi penelitian ini didasari karena Kabupaten Berau adalah salah satu kabupaten yang maju di Provinsi Kalimatan Timur serta Kabupaten Berau sangat dekat dengan lokasi ibukota baru di Kalimantan Timur. Kabupaten Berau adalah Kabupaten yang terletak di Provinsi Kalimantan Timur.

Letak geografis Kabupen Berau berada di antara $1^{\circ}-2^{\circ} 33^{\prime}$ dan $116^{\circ}-118^{\circ} 57$, berada diatas ketingian laut antara 5 dan $55 \mathrm{~m}$ dan memiliki luas wilaya sekitar 34.127.17 $\mathrm{km} 2$. Kabupaten Berau juga sering disebut "Bumi Batiwakkal" yang artinya usaha masyarakatnya tidak henti-hentinya dalam melaksanakan tugas dan kewajibannya. Kabupaten Berau juga meliputi $13.93 \%$ dari total seluruh wilayah Provinsi Kalimantan Timur.

Adapun perbatasan wilayah yang berada di sekitar Kabupaten Berau adalah sebelah Utara berbatasan dengan Kabupaten Bulungan, sebelah Selatan berbatasan dengan 
Kabupaten Kutai Timur, sebelah Timur berbatasan dengan Selat Makassar, sebelah Barat berbatasan dengan Kutai Kartanegara

\section{Potensi Ekowisata di Kabupaten Berau Provinsi Kalimantan Timur}

Setelah melakukan penelitian di Kabupten Berau, terdapat banyak potensi dan daya tarik wisata yang ditemukan selama melakukan penelitian ini, adapun dalam penelitian ini terdapat 17 potensi wisata.

Aktivitas dan kegiatan pariwisata di Kabupaten Berau, terdapat beberapa daya tarik wisata yang memiliki unsur ekowisata sehingga bisa dibuat menjadi paket ekowisata yang dapat menarik minat bagi wisatawan saat mengunjungi Kabupaten Berau. Terdapat beberapa unsur ekowisata yang dapat ditemukan dalam penelitian ini adalah konservasi, edukasi dan pemberdayaan masyarakat

Adapun dari 17 potensi ekowisata tersebut, dibagi menjadi tiga jenis yaitu potensi wisata alam, potensi wisata budaya dan potensi wisata buatan.

\section{Potensi Wisata Alam}

Wisata alam adalah semua yang berasal dari sumber daya alam yang di usahakan dan dimanfaatkan untuk menjadi objek wisata sehingga bisa dinikmati dan memberikan wisatawan rasa puas. Adapun wisata alam dalam penelitian ini harus mencakup setidaknya salah satu dari unsur ekowisata yaitu konservasi, edukasi, dan pemberdayaan masyarakat

Potensi ekowisata alam yang terdapat di Kabupaten Berau cukup banyak, adapun dalam penelitian ini terdapat 11 potensi ekowisata alam yang diidentfikasikan dan di kemas menjadi paket ekowisata, salah satunya adalah Puncak Ketepu. Di Puncak Ketepu wisatawan dapat mendaki gunung karts yang tidak terlalu curam, lalu dalam perjalanan wisatawan akan melihat berbagai macam jenis pohon dan tumbuhan serta berbagai macam hewan endemik di Kabupaten Berau. Atraksi wisata yang dapat ditemukan di Puncak Ketepu adalah pendakian dan perjalanan dengan pemandangan yang indah, selain itu udaranya yang sejuk karena ditutupi oleh hutan yang lebat sehingga wisatawan dapat menikmati udara segar dan sejuk saat akan mendaki maupun saat sudah mencapai Puncak Ketepu.

Kemudian tidak jauh dari Puncak Ketepu, terdapat situs purbakala yang bernama Gua Liang Bloyot dimana gua tersebut terdapat bekas telapak tangan yang dipercaya merupakan telapak tangan manusia purba zaman prasejarah. Banyak wisatawan maupun peneliti dari luar negeri tertarik untuk datang karena ini melihat dan juga mempelajari situs purbakala yang terdapat di Gua Liang Bloyot.

Di Gua Bloyot terdapat cap telapak tangan dan beberapa gambar hewan di dinding gua yang diprediksi berusia sekitar 2.000-4.000 tahun, gua bloyot juga merupakan permukiman manusia purba, tempat istirahat bernama wiskey namun beberapa peneliti mengemukakan bahwa Gua Bloyot hanya sebagai tempat persinggahan dan berteduh sementara.

Danau Nyadeng terletak di daerah Hutan Merabu sangat dekat lokasinya dengan Puncak Ketepu dan Gua Liang Bloyot. Di dasar Danau Nyadeng terdapat ikan-ikan dan terumbu karang. Air di Danau Nyadeng yang berwarna hijau tosca berasal dari Puncak Ketepu yang merupakan gunung karst lalu melewati gua sehingga warna air terjadi karena berasal dari gunung karst. Danau ini terletak tepat di tengah Hutan Merabu yang merupakan hutan yang memiliki banyak jenis pohon dan aneka ragam hayati yang tersebar di seluruh Hutan Merabu dan juga berbagai macam pohon dan terletak tepat di kaki Gunung Karts dan Danau Nyadeg memiliki luas sekitar satu hektar dan memiliki cabang aliran anak sungai dengan panjang tidak kurang dari empat ratus meter Adapun saat ini Danau Nyadeng dikelola oleh organisasi masyarakat lokal yang bernama Merabu Ecotourism Center

Kampus Orangutan merupakan tempat bagi hewan endemik Pulau Kalimantan yang mendekati kepunahan, yaitu Orangutan. Di Kampus Orangutan wisatawan dapat melihat dan mempelajari kehidupa sehari-hari orangutan sekaligus melihat bagaimana pengelola melestarikan lingkungan yang nyaman dan aman bagi orangutan sekaligus merawat orangutan sehingga kegiatan pengelola Kampus Orangutan merupakan 
bentuk konservasi dan edukasi bagi wisatawan yang berkunjung. Sebagai salah satu flora khas Pulau Kalimantan yang masuk dalam kategori hampir punah, Kampus Orang Utan memiliki fasilitas dan juga luas habitat yang cukup besar sehingga memudahkan Orang Utan untuk dilestarikan dan tetap dilindungi namun tetap dapat berkeliaran bebas tanpa harus takut diburu

Wisata Mangrove Tanjung Batu merupakan wisata mangrove yang paling terkenal yang ada di Kabupaten Berau. Wisata Mangrove Tanjung Batu menyajikan informasi mengenai mangrove di Pusat Informasi Mangrove (PIM). Selain itu banyak tumbuhan dan pohon-pohon mangrove yang ada di Tanjung Batu dapat dipelajari oleh wisatawan, terdapat juga fasilitas yang menunjung aktivitas wisatawan seperti jalur trecking sepanjang $1.7 \mathrm{Km}$.

Kemudian ada Pulau Sangalaki yang merupakan pulau kecil tempat konservasi penyu hijau paling besar di Kawasan Asia Tenggara. Selain penyu hijau, terdapat juga biota laut lainnya dan pemandangan bawah laut seperti terumbu karang yang sangat indah. Pasir pantai memiliki lebar 11-16 meter. Karena memiliki taman laut di sekitaran perairannya, Pulau Sangalaki menjadi terkenal karena wisata menyelamnya. Banyak sekali julukan yang diberikan kepada Pulau Sangalaki karena memiliki banyak titik penyelam sepertu Channel Entrance, Manta Run, Manta Parade, dan Sherwood Forest.

Selanjutnya ada Air Terjun Bidadari yang terletak di Kecamatan Biduk-Biduk. Air Terjun Bidadari merupakan air terjun yang memiliki bentuk unik yang saat ini sedang di kelola oleh masyarakat lokal di Kawasan Teluk Sumbang Sigending. Dinamai air terjun Bidadari karena konon katanya masyarakat lokal sering melihat bidadari mandi di air terjun tersebut. Untuk menuju ke Air Terjun Bidadari cukup mudah karena dapat menggunakan ketinting maupun dengan berjalan kaki.

Pulau Kaniungan terletak di Kecamatan Biduk-biduk ini memiliki dua pulau yaitu Pulau Kaniungan Besar dan Pulau Kaniungan Kecil. Atraksi wisata yang ada di Pulau
Kaniungan adalah wisatawan dapat melakukan kegiatan diving dan snorkeling untuk berenang dengan biota laut maupun untuk melihat pemandangan bawah laut seperti terumbung karang yang saat ini masuk dalam konservasi.

Kemudian ada potensi ekowisata Whale Shark di Pantai Talisay, disini wisatawan dapat melihat sekaligus berenang dengan ikan hiu macan tutul yang terkenal langka dan cukup sulit untuk ditemui, biasanya ikan hiu macan tutul sering muncul ke permukaan saat pagi maupun sore hari. Wisatawan akan dibawa oleh kapal kecil menuju tengah laut untuk berenang dan menyelam dengan ikan hiu macan tutul. melihat flora dan fauna yang ada di Pantai Talisay.Selain memiliki beberapa jenis flora laut yang unik dan khas, Pantai Talisay sangat indah pemandangan pantai yang menakjubkan, laut yang biru bersih. Di sekitar Pantai Talisay juga terdapat banyak café dan rumah makan yang banyak sehingga memudahkan wisatawan yang berkunjung untung sekedar istirahat minum maupun makan.

Air Panas Asin Pemapak Biatan merupakan sumber air panas alami yang ada di Kabupaten Berau. Air Panas Asin Pemapak Biatan memiliki dua jenis air yaitu tawar di permukaan dan air asin di bawah permukaan. Objek wisata ini menawarkan pemandian air panas yang berada di kolam alami dan sensasi mandi yang segar dengan air yang jernihAir panas Pemapak Biatan ini dapat mengencerkan padatan mineral tinggi seperti kalsium, litium, ataupun radium.Adapun sumber Air Panas Asin Pemapak Biatan dipercaya dapat menyembuhkan berbagai macam jenis penyakit dan dapat membuat tubuh menjadi lebih rileks dan lebih santai.

Potensi ekowisata alam yang terakhir yang ada di dalam penelitian ini adalah Danau Labuan Cermin yang terletak di Kecamatan Biduk-Biduk Dinamai Labuan Cermin karena airnya yang sangat jernih dan memiliki dua jenis air yaitu air tawar dan asin bercampur jadi satu. Di Danau Labuan Cermin kegiatan yang dapat dilakukan adalah mengitari danau dengan kapal kecil, berenang dan snokrkeling untuk melihat pemandangan dasar danau yang sangat indah. Danau Labuan Cermin memiliki atraksi wisata yang cukup beragam, selain 
wisatawan dapat berenang, menyewa kapal untuk sekedar memutari danau dan berswafoto, wisatawan juga dapat melakukan kegiatan snorkeling sehingga dapat melihat pemandangan bawah laut dan ikan-ikan yang hidup di Danau Labuan Cermin tersebut.

\section{Potensi Wisata Budaya}

Selain potensi ekowisata alam, di Kabupaten Berau juga terdapata Wisata Budaya unik yang tentunya dapat di kemas menjadi paket ekowisata. Wisata Budaya adalah segala sesuatu yang berupa daya tarik yang berasal dari seni dan kreasi manusia. Adapun dalam penelitian ini wisata budaya yang memiliki unsur ekowisata yaitu konservasi, edukasi dan permbedayaan masyarakat.

Kampung Budaya Bena Baru. Di Kampung Budaya Bena Baru wisatawan akan melihat berbagai macam budaya Suku Dayak pedalaman mulai dari kehidupan sehari-hari, makanan khas, tarian, alat music maupun cara beribadah untuk menghormati leluhur dan nenek moyang. Wisatawan juga dapat melihat para tetua suku Dayak yang memiliki kuping panjang yang merupakan salah satu ciri khas Suku Dayak. Adapun mayoritas penduduk Kenyah Badeng merupakan suku Dayak dan beragama Kristen protestan yang selain menjadi petani mereka berkebun seperti tanaman sayuran, cokelat, mereka juga memiliki kebun pisang

Kemudian wisata budaya yang ditemukan di Kabupaten Berau adalah Kawasan Teluk Sumbang Sigending, disini wisatawan dapat melihat dua suku yaitu Suku Bugis dan Suku Dayak hidup berdampingan suku bugis kebanyakan menjadi nelayan karena hidup dekat perairan sementara suku dayak menjadi petani karena tempat tinggal mareka berada di dataran tinggi. Selain itu terdapat banyak biota laut dan feeding ground yang ditemukan di Kawasan Sumbang

Potensi wisata budaya yang terakhir dalam penelitian ini adalah Keraton Sambaliung. Keraton Sambaliung merupakan bukti sejarah adanya kesultanan di Kabupaten Berau semasa zaman penjajahan Belanda hingga zaman penjajahan Jepang. Di dalam Keraton Sambaliung terdapat berbagai macam benda-benda pusaka dari raja-raja dan sultan yang memerintah dan memimpin Sambaliung sejak zaman dahulu.

\section{Potensi Wisata Buatan}

Wisata Buatan adalah segala sesuatu yang berasal dari karya manusia, dan dapat dijadikan sebagai objek wisata seperti bendabenda sejarah, kebudayaan, religi serta tata cara manusia.

Adapun wisata buatan yang ada dalam penelitian ini terdapat unsur ekowisata yaitu konservasi, edukasi dan pemberdayaan masyarakat.Potensi ekowisata buatan yang terdapat di Kabupaten Berau yang dapat di kemas menjadi paket ekowisata cukup banyak, salah satunya adalah Museum Batiwakkal Gunung Tabur. Di Museum Batiwakkal ini terdapat berbagai macam sejarah tentang Kabupaten Berau dan berbagai macam bendabenda bersejarah yang di simpan, selain itu terdapat pemandu wisata lokal yang akan menemani wisatawan saat mengunjungi Museum Batiwakkal dan menjelaskan setiap benda-benda dan cerita-cerita masyarakat lokal di Kabupaten Berau

Kemudian ada Wisata Buah Labanan yang merupakan perkebunan buah yang menghasilkan buah-buah khas Kalimantan Timur seperti Buah Lai, wisatawan dapat ikut belajar menanam pohon, belajar melihat cara kawin silang antar tumbuhan/buah, dan membeli bibit buah untuk dibawa pulang dan ditanam dirumah, selain itu wisatawan dapat berkeliling Wisata Buah Labanan dengan menggunakan mobil dan disini juga menyediakan kendaraan APV sehingga wisatawan bisa jalan-jalan.

Potensi wisata buatan terakhir adalah Pasar Tradisional Sannggam Adji Dilayas. Dinamai pasar sanggam karena memiliki arti yaitu "bagus" atau "indah" dalam bahas Kutai. Di pasar tradisional ini wisatawan dapat membeli berbagai jenis barang dan makanan khas Kabupaten Berau, mulai dari cinderamata, cemilan, maupun kerajinan tangan khas Berau dapat di temui dan di beli di Pasar Tradisional Sanggam Adji Dilayas.

\section{Pengemasan Paket Ekowisata di Kabupaten Berau}

Setelah melakukan identifikasi potensi ekowisata yang ada di Kabupaten Berau, 
terdapat 17 potensi ekowisata yang dapat di kemas menjadi empat paket ekowisata dengan rincian tiga paket ekowisata fullday dan satu paket ekowisata $2 \mathrm{H} 1 \mathrm{M}$ dengan itinerary berbentuk uraian, tabel dan grafik, sementara jenis paket ekowisatadalam penelitian ini adalah ready made tour.

Adapun dalam mengemas suatu paket wisata, terdapat beberapa hal yang perlu dipertimbangkan agar wisatawan merasa puas, aman dan nyaman. Adapun hal-hal yang perlu di pertimbangkan tersebut adalah waktu tempuh dan rute antar objek, variasi objek, starting point, finishing point, dan perhitugan harga wisata

Adapun perhitungan harga wisata harus sesuai dengan apa yang ada di iteneray dan wisatawan mendapatkan semua yang di itinerary tersebut. Adapun harga wisata sebaiknya tidak terlalu mahal tetapi tetap menguntungkan pihak tour operator.

Adapun harga dari suatu perjalanan wisata meliputi Harga Paket Ekowisata Per Orang/Net Price yaitu harga wisata merupakan jumlah keseluruhan biaya yang dikeluarkan untuk mengelola wisata ditambah dengan kentungan yang diharapkan. Selanjutnya ada harga Jual Paket Ekowisata secara Kolektif. Harga Jual secara kolektif adalah apabila peserta dalam acara wisata lebih dari satu orang, maka ada biaya yang ditanggung bersama (Variabel Cost) sehingga harga paket menjadi lebih murah. Kemudian ada harga Dengan FOC (Free of Charge) yaitu Complimentary sering disebut juga free of charge (FOC) yaitu pembebasan suatu jumlah peserta tertentu dari pembayaran jika syarat yang ditentukan oleh tour operator telah terpenuhi. Yang terrakhir adalah Harga Jual dengan Komisi Agen yaitu penjualan produk wisata dapat dilakukan dengan dua cara yaitu secara langsung maupun tidak langsung (melalui perantara). Adapun melakukan penjualan secara tidak langsung (melalui perantara), maka tour operator memberikan jasa imbalan kepada perantara berupa komisi agen (agency commission) sebesar 10\% dari harga wisata yang telah ditentukan, setelah mendapatkan harga jual dalam Rupiah (IDR) akan dibulatkan dalam bentuk kurs US Dollar.
Adapun judul dari empat paket ekowisata tersebut adalah Berau Culture and City Tour yang merupakan paket wisata yang berfokus pada wisata budaya dan Kota Berau, paket wisata ini termasuk fullday tour karena memiliki durasi 9 jam, Berau Mangrove and Sangalaki Island Tour, paket wisata yang berfokus pada sejarah berau dan wisata alam yang ada di Kabupaten Berau, paket wisata ini termasuk fullday tour dengan durasi 11 jam. Selanjutnya paket wisata yang berjudul Orangutan University and Merabu Forest Tour, paket wisata ini berfokus pada daerah pedesaan dan hutan yang ada di Kabupaten Berau dengan durasi perjalanan 13 jam sehingga termasuk dalam fullday tour. Paket wisata yang terakhir bernama Lake Mirror and Whale Shark Tour, paket wisata ini memiliki durasi 22 jam, sehingga dibagi menjadi paket wisata 2 hari 1 malam

Tabel 1.

Judul Paket Ekowisata di Kabupaten Berau Provinsi Kalimantan Timur

\begin{tabular}{|c|c|c|c|}
\hline $\begin{array}{l}\text { Judul Paket } \\
\text { Ekowisata }\end{array}$ & $\begin{array}{l}\text { Jenis } \\
\text { Paket }\end{array}$ & $\begin{array}{c}\text { Waktu } \\
\text { Tempuh }\end{array}$ & Daya Tarik Wisata \\
\hline $\begin{array}{l}\text { Berau } \\
\text { Culture } \\
\text { and City } \\
\text { Tour }\end{array}$ & Fullday & 9 jam & $\begin{array}{ll}\text { 1. } & \text { Keraton Sambailiung } \\
\text { 2. } & \text { Wisata Buah Labanan } \\
\text { 3. } & \text { Kampung Bena Baru } \\
\text { 4. } & \text { Pasar Tradisional SAD }\end{array}$ \\
\hline $\begin{array}{c}\text { Berau } \\
\text { Mangrove } \\
\text { and } \\
\text { Sangalaki } \\
\text { Island Tour }\end{array}$ & Fullday & $11 \mathrm{Jam}$ & $\begin{array}{ll}\text { 1. } & \text { Museum Batiwakkal } \\
\text { 2. } & \text { Pasar Tradisional SAD } \\
\text { 3. } & \text { Mangro Tanjung Batu } \\
\text { 4. } & \text { Pulau Sangalaki }\end{array}$ \\
\hline $\begin{array}{c}\text { Orangutan } \\
\text { University } \\
\text { Merabu } \\
\text { Forest } \\
\text { Tour }\end{array}$ & Fullday & 13 jam & $\begin{array}{ll}\text { 1. } & \text { Puncak Ketepu } \\
\text { 2. } & \text { Goa Liang Bloyot } \\
\text { 3. } & \text { Danau Nyadeng } \\
\text { 4. } & \text { Kampus Orangutan }\end{array}$ \\
\hline $\begin{array}{c}\text { Lake } \\
\text { Mirror and } \\
\text { Whale } \\
\text { Shark Tour }\end{array}$ & $\begin{array}{l}2 \text { Hari } \\
1 \\
\text { Malam }\end{array}$ & 22 jam & $\begin{array}{ll}\text { 1. } & \text { Sumbang Sigending } \\
\text { 2. } & \text { Air Terjun Bidadari } \\
\text { 3. } & \text { Pulau Kaniungan } \\
\text { 4. } & \text { Labuan Cermin } \\
\text { 5. } & \text { Whale Shark } \\
\text { 6. } & \text { Air Panas Biatan }\end{array}$ \\
\hline
\end{tabular}

\section{Paket Ekowisata Berau Culture and City Tour}

Kegiatan pertama wisatawan dalam paket wisata ini adalah sarapan pada pukul 08.00. selanjutnya wisatawan akan dijemput di hotel pada pukul 08.30 untuk berkunjung ke Keraton Sambaliung dan tiba pada pukul 08.40. Wisatawan dapat langsung masuk ke 
Keraton Sambaliung untuk melihat istana Raja-raja zaman dahulu dan melihat tempat singgasana Raja, selain itu wisatawan juga dapat melihat dan berfoto dengan mayat buaya raksasa yang di pajang didalam lemari kaca berukuran besar, disini wisatawan mendapatkan arahan dari pengurus Keraton Sambaliung yang akan menjelaskan secara detail tentang sejarah Keraton Sambaliung. Tepat pada pukul 10.00 kunjungan di Keraton Sambaliung selesai dan wisatawan harus berkumpul untuk melanjutkan perjalanan ke daya tarik wisata selanjutnya

Pukul 10.00 wisatawan akan diajak untuk menuju ke daya tarik wisata selanjutnya yaitu Wisata Buah Labanan. Pada pukul 10.55 wisatawan tiba di Wisata Buah Labanan dan wisatawan langsung di ajari bagaimana cara mengawinkan silang sebuah bibit buah, selain itu wisatawan juga dapat memulai ikut menanam bibit dan juga membeli bibit untuk dibawa pulang, selain itu wisatawan juga dapat membeli buah lai yang sudah jadi dan siap dimakan. Di Wisata Buah Labanan juga menyediakan minibus dan juga ATV untuk wisatawan berkeliling taman dan bermain di sekitar taman dengan menggunakan ATV. Perjalanan di Wisata Buah Labanan berakhir pada pukul 12.00. Setelah itu wisatawan akan diajak ke restoran Rumah Makan Pondok Selero untuk menyantap makan siang dan juga istirahat serta sholat bagi yang menunaikan sampai. Makan siang dan sholat selesai pukul 12.55

Pukul 12.55, setelah makan siang, wisatawan akan diajak untuk menuju ke Kampung Bena Baru. Pada pukul 13.30 wisatawan sampai di Kampung Bena Baru, di sini wisatawan akan menikmati hidangan ringan khas Berau dan makanan khas dayak yaitu kue rangai. Setelah itu wisatawan akan disuguhkan tari dayak dan wisatawan juga dapat melihat wanita dengan daun cuping yang panjang, mendengarkan para tetua bercerita dan dapat berfoto-foto dengan berbagai ukiran khas dayak dan wisatawan dapat membeli kerajinan tangan yang ada di Kampung Bena Baru, wisata di Kampung Bena Baru pun selesai pada pukul 15.00.

Pukul 15.00 wisatawan akan kembali berkumpul karena akan bersiap-siap untuk menuju ke daya tarik wisata yang terakhir yaitu Pasar Tradisional Sanggam Adji Dilayas. Pada pukul 15.55, rombongan tiba di Pasar Tradisional Sanggam Adji Dilayas. Di Pasar Tradisional ini wisatawan dapat membeli pernak-pernik yang berbau Kabupaten Berau, penyu, pesut, dan juga kerajinan tangan seperti tas, gelang, dan juga gantungan kunci yang memiliki ukiran dayak Khas Kabupaten Berau, selain itu wisatawan juga dapat membeli makanan Khas Kabupaten Berau.

Pada pukul 17.00, rombongan wisatawan harus berkumpul di tempat parkir dan bersiap untuk kembali ke hotel tempat wisatawan menginap. Pada pukul 17.15 wisatawan sudah sampai di Hotel, wisata selesai.

Tabel 2.

Harga Paket Ekowisata Berau Culture and City Tour

\begin{tabular}{lccccc}
\hline \multicolumn{1}{c}{ Ket. } & \multicolumn{5}{c}{ Jumlah Peserta } \\
\cline { 2 - 6 } & $\mathbf{1}$ & $\mathbf{2}$ & $\mathbf{3}$ & $\mathbf{4 - 6}$ & $\mathbf{7 - 9}$ \\
\hline $\begin{array}{l}\text { Harga Per } \\
\text { Peserta }\end{array}$ & Rp. & Rp. & Rp. & Rp. & Rp. \\
& 1.412 .500 & 790.625 & 583.332 & 526.562 & 444.642 \\
\hline $\begin{array}{l}\text { Harga } \\
\text { dengan }\end{array}$ & & & & & Rp. \\
FOC & & & & & 521.082 \\
\hline $\begin{array}{l}\text { Harga } \\
\text { dengan }\end{array}$ & 1.659 .000 & 878.502 & 648.146 & 585.068 & 578.980 \\
$\begin{array}{l}\text { Komisi } \\
\text { Agen 10\% }\end{array}$ & & & & & \\
\hline $\begin{array}{l}\text { Harga Jual } \\
\text { dalam }\end{array}$ & US\$ 115 & US\$ 61 & US\$ 45 & US\$ 41 & US\$ 40 \\
US\$ & & & & & \\
\hline
\end{tabular}

\section{Paket Ekowisata Berau Mangrove and Sangakali Island Tour}

Wisatawan akan diajak ke Museum Batiwakkal yang merupakan museum kebanggan masyarakat Kabupaten Berau, sehingga dapat mempelajari sejarah dan kesultanan Kabupaten Berau. Museum Batiwakkal dulunya adalah Kerajaan Gunung Tabur yang merupakan Setelah itu wisatawan akan diajak untuk berkunjung ke Pasar Tradisonal Sanggam Adji Dilayas untuk berbelanja dan jalanjalan. Setelah itu wisatawan akan di ajak ke Pelabuha Mangrove Tanjung Batu dan menyeberang ke Pulau Sangalaki.

Aktivitas wisatawan dalam paket wisata ini dimulai pada pukul 07.00 yaitu 
sarapan dan berkumpul di Neotel Berau City Center. Selanjutnya pada pukul 07.30 perjalanan dilakukan untuk menuju ke Museum Batiwakkal dan rombongan wisatawan diperkiraan tiba di Museum Batiwakkal pada pukul 07.50, setelah itu wisatawan akan dipandu oleh guide lokal yang khusus menangani wisatawan di Museum Batiwakkal untuk memberikan pengetahuan baru dan cerita-cerita rakyat setempat kepada wisatawan. Pada pukul 08.50, kunjungan wisatawan di Museum Batiwakkal selesai dan rombongan wisatawan bersiap untuk berangkat ke daya tarik wisata selanjutnya, yaitu Pasar Tradisional Sanggam Adji Dilayas

Pada pukul 09.02, rombongan wisatawan tiba di Pasar Tradisional Sanggam Adji Dilayas. . Di Pasar Tradisional ini wisatawan dapat membeli pernak-pernik yang berbau Kabupaten Berau, penyu, pesut, dan juga kerajinan tangan seperti tas, gelang, dan juga gantungan kunci yang memiliki ukiran dayak Khas Kabupaten Berau, selain itu wisatawan juga dapat membeli makanan Khas Kabupaten Berau maupun cemilan/makanan ringan seperti amplang, ikan rabuk, dan juga kacang-kacangan. Pada pukul 10.00, kunjungan wisatawan di Pasar Tradisional Sanggam Adji Dilayas selesai, selanjutnya wisatawan akan melanjutkan perjalanan ke Mangrove Tanjung Batu

Pada pukul 12.00, wisatawan tiba di lokasi Mangrove Tanjung Batu, selanjutnya wisatawan akan istirahat dan makan siang di restoran yang terletak di Mangrove Tanjung Batu, yaitu Rumah Makan Ilham, pada pukul 12.30, wisatawan selesai istirahat dan makan siang, selanjutnya akan wisatawan akan mengunjungi daya tarik wisata Mangrove Tanjung Batu. Disini wisatawan dapat melakukan berbagai atraksi wisata seperti menikmati jalur tracking, pengamatan satwa dan keberagaman pohon mangrove, rekreasi dengan keluarga. Pada pukul 13.30, wisata di Mangrove Tanjung batu selesai, selanjutnya rombongan wisatawan akan dibawa ke Pelabuhan Tanjung Batu yang tidak jauh dari Hutan Mangrove tersebut untuk menuju ke daya tarik wisata yang terakhir yaitu Pulau Sangalaki.

Pada pukul 13.30 wisatawan akan menaiki kapal cepat dengan yang telah tersedia dan perkiraan untuk sampai di Pulau Sangalaki adalah pada pukul 14.05. Setelah sampai di Pulau Sangalaki, wisatawan dapat langsung melanjutkan aktivitas wisata dengan menikmati pasir dan pantai di Pulau Sangalaki, selain itu dapat melakukan kegiatan Snorkeling untuk melihat pemandangan bawah laut terumbu karang, setelah itu wisatawan juga dapat melihat hewan seperti Manta Ray, dan melihat pelestarian Penyu Hijau yang setiap harinya akan di lepas ke laut kembali. Pada pukul 15.25, wisata di Pulau Sangalaki selesai dan wisatawan bersiap untuk ke kapal untuk kembali ke Pelabuhan Tanjung Batu.

Pada pukul 16.00 wisatawan telah sampai di Pelabuhan Tanjung Batu selanjutnya menggunakan mobil untuk kembali ke hotel tempat wisatawan menginap. Rombongan wisatawan diperkirakan sampai di hotel pada pukul 18.00 dan wisata selesai.

Tabel 3.

Harga Paket Ekowisata Berau Mangrove and Sangalaki Island Tour

\begin{tabular}{|c|c|c|c|c|c|}
\hline \multirow[t]{2}{*}{ Ket. } & \multicolumn{5}{|c|}{ Jumlah Peserta } \\
\hline & 1 & 2 & 3 & $4-6$ & $7-9$ \\
\hline $\begin{array}{l}\text { Harga Per } \\
\text { Peserta }\end{array}$ & $\begin{array}{c}\text { Rp. } \\
1.818 .750\end{array}$ & $\begin{array}{c}\text { Rp. } \\
1.028 .125\end{array}$ & $\begin{array}{c}\text { Rp. } \\
764.582\end{array}$ & $\begin{array}{c}\text { Rp. } \\
679.687\end{array}$ & $\begin{array}{c}\text { Rp. } \\
561.606\end{array}$ \\
\hline $\begin{array}{l}\text { Harga } \\
\text { dengan } \\
\text { FOC }\end{array}$ & & & & & $\begin{array}{c}\text { Rp. } \\
655.207\end{array}$ \\
\hline $\begin{array}{l}\text { Harga } \\
\text { dengan } \\
\text { Komisi } \\
\text { Agen } \\
10 \%\end{array}$ & $\begin{array}{c}\text { Rp. } \\
2.020 .833\end{array}$ & $\begin{array}{c}\text { Rp. } \\
1.142 .361\end{array}$ & $\begin{array}{c}\text { Rp. } \\
849.535\end{array}$ & $\begin{array}{c}\text { Rp. } \\
755.687\end{array}$ & $\begin{array}{c}\text { Rp. } \\
728.000\end{array}$ \\
\hline $\begin{array}{l}\text { Harga } \\
\text { Jual } \\
\text { dalam } \\
\text { US\$ }\end{array}$ & US\$ 139 & US\$ 79 & US\$ 59 & US\$ 52 & US\$ 50 \\
\hline
\end{tabular}

\section{Paket Ekowisata Orangutan University and Merabu Forest Tour}

Paket ekowisata ini akan diawali dengan penjemputan wisatawan pada pukul 04.00 di Neotel Berau City Center karena jarak yang lumayan jauh ke Kawasan Merabu. Setelah itu wisatawan akan berangkat menuju Merabu Ecoutursm Center dengan durasi 150 menit dengan perkiraan sampai Merabu Ecourism Center pada pukul 06.30.

Setelah sampai di Merabu Ecotourism Center pada pukul 06.30, wisatawan akan langsung diajak untuk wisata tracking menuju Puncak Ketepu dan perkiraan untuk sampai ke Puncak Ketepu adalah 35 menit karena medan yang tidak terlalu sulit dan dataran tanah tidak terlalu curam sehingga landai dan 
memudahkan wisatawan dalam perjalanan. Pada pukul 07.05 wisatawan sudah berada di Puncak Ketepu untuk menikati suasana sejuk dan dapat berswafoto. Wisatawan juga dapat makan cemilan dan makanan ringan sambil menikmati sunrise dan kabut yang ada di Puncak Ketepu. Aktivitas wisatawan di Puncak pada pukul 08.30 selanjutnya wisatawan akan menuju daya tarik wisata selanjutnya yaitu Liang Bloyot.

Pada pukul 09.30, wisatawan sampai di Liang Bloyot untuk melihat situs purbakala berupa lukisan hewan-hewan dan juga jejak tangan yang ditinggalkan oleh manusia purba. Wisatawan juga dapat melihat bentuk gua dan kedalaman gua sehingga mengetahui bagaimana manusia purba saat tinggal dahulu. Adapun sebelum sampai di Goa Lia Bloyot wisatawan akan mampir dulu ke tempat Gua habitat kelelawar. Pada pukul 10.00 wisata di Liang Bloyot selesai, selanjutnya wisatawan akan menuju ke Danau Nyadeng.

Pada pukul 10.30, wisatawan sampai di Danau Nyadeng, disini wisatawan dapat melakukan kegiatan wisata seperti berenang, snorkeling, bersantai di bibir danau maupun berfoto, selain itu wisatawan juga akan makan siang di Danau Nyadeng sambil menikmati pemandangan Hutan Merabu dan Danau Nyadeng, selain itu wisatawan juga akan makan siang berupa nasi kotak di Danau Nyadeng. Tepat pada pukul 12.00 wisata di Danau Nyadeng sekaligus makan siang selesai, wisatawan akan kembali ke Merabu Ecotourism Center dan sampai disana pada pukul 12.35 selanjutnya wisatawan akan bersiap untuk berangkat ke daya tarik wisata selanjutnya dan yang terakhir yaitu Kampus Orangutan yang ditempuh dari Merabu Ecouturism Center selama 1 jam.

Pada pukul 13.35 wisatawan sampai di Kampus Orangutan, di daya tarik wisata ini wisatawan dapat melihat berbagai macam tingkah laku dan kehidupan sehari-hari Orangutan yang merupakan hewan endemic Pulau Kalimantan, Tepat pada pukul 14.30 wisata di Kampus Orangutan selesai dan wisatawan akan dibawa kembali ke hotel dan tiba di Hotel Tanjung Radeb pada pukul 17.30 dan wisata selesai.
Tabel 4.

Harga Paket Ekowisata Orangutan and Merabu Forest Tour

\begin{tabular}{lccccc}
\hline \multicolumn{1}{c}{ Ket. } & \multicolumn{5}{c}{ Jumlah Peserta } \\
\cline { 2 - 6 } & $\mathbf{1}$ & $\mathbf{2}$ & $\mathbf{3}$ & $\mathbf{4 - 6}$ & $\mathbf{7 - 9}$ \\
\hline $\begin{array}{l}\text { Harga Per } \\
\text { Peserta }\end{array}$ & Rp. & Rp. & Rp. & Rp. & Rp. \\
& 1.443 .750 & 815.250 & 606.250 & 548.437 & 465.177 \\
\hline $\begin{array}{l}\text { Harga } \\
\text { dengan }\end{array}$ & & & & \\
FOC & & & & Rp. \\
\hline $\begin{array}{l}\text { Harga } \\
\text { dengan }\end{array}$ & Rp. & Rp. & Rp. & Rp. & Rp. \\
$\begin{array}{l}\text { Komisi } \\
\text { Agen 10\% }\end{array}$ & 1.604 .166 & 905.833 & 673.611 & 609.374 & 603.000 \\
\hline $\begin{array}{l}\text { Harga Jual } \\
\text { dalam US\$ }\end{array}$ & US\$ 110 & US\$ 62 & US\$ 47 & US\$ 42 & US\$ 42 \\
\hline
\end{tabular}

\section{Paket Ekowisata Mirror Lake and Whale Shark Tour}

Paket ekowisata Lake Mirror and

Whale Shark Tour ini berbeda dari paket wisata sebelumnya karena tidak seperti paket sebeumnya karena paket ekowisata ini akan berdurasi 2 hari dan 1 malam sehingga wisatawan akan menginap dan melanjutkan perjalanan wisata pada esok harinya. Hal ini terjadi karena jarak antar daya tarik wisata cukup jauh sehingga membutuhkan waktu yang cukup lama untuk sampai.

Adapun paket ekowisata ini menawarkan daya tarik wisata yang ada di Zona Perairan (Shore Zone) sehingga wisatawan dapat melihat keindahan laut dan bawah laut yang ada di Kabupaten Berau. Kegiatan ekowisata yang dilakukan oleh wisatawan dalam paket ini adalah dapat menemui salah satu hewan langka yang juga menjadi tempat konservasi yang ada di Kabupaten Berau yaitu Hiu Paus yang ada di Pantai Talisay.Paket ekowisata ini dibagi menjadi dua bagian yaitu hari pertama dan hari kedua. Hari pertama dalam paket ekowisata ini, perjalanan wisatawan dalam paket ini akan diawali dengan wisatawan sarapan dan berkumpul di hotel pada pukul 07.00, setelah semua sudah siap wisatawan akan menuju daya tarik wisata yang pertama yaitu Kawasan Sumbang Sigending. Wisatawan sampai di Teluk Sumbang Sigending sekitar pukul 10.30.

Wisatawan sampai di Teluk Sumbang Sigending pada pukul 10.30 dan berkunjung. Kegiatan wisatawan selama di Teluk Sumbang 
Sigending adalah dapat melihat Suku Bugis dan Suku Dayak Basap, selain itu disini wisatawan dapat melihat panorama alam, hutan mangrove dan terumbu karang yang indah. Aktivitas utama wisatawan di sini adalah dapat memberikan makan ke biota laut seperti penyu, ikan dan bintang laut di feeding ground yang telah di sediakan. Pada pukul 12.00 wisata di Teluk Sumbang Sigending selesai.

Pada pukul 12.00 wisatawan akan langsung diajak untuk makan siang dengan lunch box yang telah disediakan oleh tour operator dan selesai makan siang pada pukul 12.30, selanjutnya wisatawan akan melanjutkan perjalanan menuju Air Terjun Bidadari selama 30 menit dengan rincian 20 menit menggunakan ketinting dan 10 menit berjalan kaki. Tepat pada pukul 13.00 wisatawan tiba di Air Terjun Bidadari dan wisatawan dapat berenang dan berfoto, pada pukul 13.45 wisata di Air Terjun Bidadari selesai.

Wisatawan akan bersiap untuk menuju Teluk Sulaiman untuk menyeberang ke daya tarik wisata selanjutnya yaitu Pulau Kaniungan. Pada pukul 13.45 wisatawan akan berangkat dari Air Terjun Bidadari menuju Teluk Sulaiman dan akan tiba di Teluk Sulaiman pada pukul 14.30 dan wisatawan akan berangkat menuju Pulau Kaniungan. Perkiraan durasi dari Teluk Sulaiman menuju Pulau Kaniungan adalah 30 menit sehingga wisatawan akan tiba tepat pada pukul 15.00.

Pukul 15.00 wisatawan telah tiba di

Pulau Kaniungan, disini wisatawan akan melihat pantai, snorkeling, dan dapat melihat budidaya penyu hijau yang merupakan hewan langka yang ada di Kabupaten Berau, disini wisatawan juga akan bermalam sehingga wisata di Pulau Kaniungan akan berakhir pada pukul 18.00 wisatawan akan bersiap untuk makan malam dan wisata pada hari pertama selesai.

Pada hari kedua dari paket ekowisata ini. Kegiatan wisatawan akan dimulai pada pukul 06.30 untuk sarapan dan berkumpul di Penginapan Pulau Kaniungan. Setelah itu wisatawan akan menuju ke pelabuhan yang ada di Pulau Kaniungan pada pukul 07.00 untuk menuju Teluk Sulaiman dengan durasi 30 menit. Setelah sampai di Teluk Sulaiman pada pukul 07.30, selanjutnya wisatawan akan bersiap menuju Pelabuhan Kelambu untuk menuju daya tarik wisata selanjutnya, yaitu Danau Labuan Cermin dengan menggunakan transportasi mobil selama 45 menit

Pada pukul 08.15, wisatawan akan tiba di Pelabuhan Kelambu untuk naik ketinting menuju Danau Labuan Cermin selama 15 menit. Pada pukul 08.30 wisatawan telah tiba di daya tarik wisata Danau Labuan Cermin. Di Labuan Cermin. Di Labuan Cermin, wisatawan dapat melakukan kegiatan wisata seperti berenang, snorkeling, naik kapal kecil untuk mengelilingi danau, berfoto, ataupun bersantai di daerah sekitar bibir danau. Pada pukul tepat 10.00 , aktivitas wisata di Danau Labuan Cermin selesai,perjalanan wisata selanjutnya yaitu menuju Pantai Talisay, perkiraan durasi perjalanan adalah dua jam.

Pada pukul 12.15, wisatawan tiba di Pantai Talisay, selanjutnya wisatawan akan makan siang terlebih dahulu di restoran yang terletak di Pantai Talisay. Wisatawan akan selesai makan siang dan istirahat pada pukul 12.45 , selanjutnya wisatawan akan naik kapal ketinting untuk pergi ke tengah laut agar dapat melihat dan berenang bersama Whale Shark. Wisata di Pantai Talisay ini akan berakhir pada pukul 14.00 , selanjutnya wisatawan akan menuju daya tarik wisata yang terakhir yaitu Wisata Air Panas Asin Pemapak Biatan. Perjalanan dari Pantai Talisay menuju Air Panas Asin Pemapak Biatan memakan durasi tepat satu jam.

Pada pukul 15.00, wisatawan akan sampai di Wisata Air Panas Asin Pemapak Biatan, disini wisatawan akan berendam untuk menghilangkan rasa lelah dan dapat bersantai sekaligus berfoto-foto,. Aktivitas wisata selesai pada pukul 16.00, selanjutnya wisatawan akan kembali ke Neotel Berau City Center di Kecamatan Tanjung Radeb dengan durasi tiga jam, pada pukul 19.00 wisatawan sampai di Hotel, wisata selesai.

Tabel 5.

Harga Paket Ekowisata Mirror Lake and Whale Shark Tour

\begin{tabular}{lccccc}
\hline \multicolumn{1}{c}{ Ket. } & \multicolumn{5}{c}{ Jumlah Peserta } \\
\cline { 2 - 6 } & $\mathbf{1}$ & $\mathbf{2}$ & $\mathbf{3}$ & $\mathbf{4 - 6}$ & $\mathbf{7 - 9}$ \\
\hline $\begin{array}{l}\text { Harga Per } \\
\text { Peserta }\end{array}$ & Rp. & Rp. & Rp. & Rp. & Rp. \\
& 1.443 .750 & 815.250 & 606.250 & 548.437 & 465.177 \\
\hline Harga & & & & \\
dengan & & & & Rp. \\
FOC & & & & \\
\hline
\end{tabular}




\begin{tabular}{|c|c|c|c|c|c|}
\hline $\begin{array}{l}\text { Harga } \\
\text { dengan } \\
\text { Komisi } \\
\text { Agen } 10 \%\end{array}$ & $\begin{array}{c}\text { Rp. } \\
1.604 .166\end{array}$ & $\begin{array}{c}\text { Rp. } \\
905.833\end{array}$ & $\begin{array}{c}\text { Rp. } \\
673.611\end{array}$ & $\begin{array}{c}\text { Rp. } \\
609.374\end{array}$ & $\begin{array}{c}\text { Rp. } \\
603.000\end{array}$ \\
\hline $\begin{array}{l}\text { Harga Jual } \\
\text { dalam US\$ }\end{array}$ & US\$ 110 & US\$ 62 & US\$ 47 & US\$ 42 & US\$ 42 \\
\hline
\end{tabular}

\section{SIMPULAN DAN SARAN Simpulan}

Berdasarkan hasil penelitian yang dilakukan di Kabupaten Berau, Provinsi Kalimantan Timur ini, terdapat 17 potensi ekowisata yang dapat di kemas menjadi paket ekowisata, yaitu Puncak Ketepu yang memiliki pemandangan pohon dan hutan, Gua Liang Bloyot yang merupakan tempat situs purbakala, Danau Nyadeng yang airnya berasal dari gunung karst, Kampus Orangutan tempat hewan Orangutan hidup dan dilestarikan, Mangrove Tanjung Batu merupakan wisata hutan mangrove, Pulau Sangalaki yang merupakan tempat konservasi penyu hijau terbesar di Asia Tenggara, Air Terjun Bidadari yang memiliki bentuk yang indah dan unik, Pulau Kaniungan yang memikiki biota laut yang unik dan pemandangan bawah laut yang indah, Danau Labuan Cermin yang memiliki tingkat kejernihan air yang tinggi, Whale Shark Pantai Talisayan tempat wisatawan berenang dengan hiu macan tutul, Air Panas Asin Pemapak Biatan yang dipercaya dapat menyembuhkan berbagai macam penyakit, Kampung Budaya Bena Baru tempat permukiman suku dayak pedalaman, Keraton Sambailiug tempat mempelajari sejarah kesultanan dan kerajaan di Kabupaten Berau, Kawasan Sumbang Sigending, yang merupakan tempat dua suku budaya tinggal, Wisata Buah Labanan tempat wisatawan belajar menanam pohon yang berbuah, Musuem Batiwakkal tempat sejarahsejarah Kabupaten Berau, dan Pasar Tradisional Sanggam Adji Dilayas merupakan pasar yang menjual kerajinan tangan khas Kabupaten Berau.

Berdasarkan hasil identifikasi potensi ekowisata diatas, dapat di buat empat macam paket ekowisata dengan rincian tiga paket ekowisata fullday dan satu paket 2H1M dengan judul Berau Culture and City Tour dengan durasi perjalanan 9 jam dengan mengunjungi 4 daya tarik wisata, Berau
Mangrove and Sangalaki Island Tour dengan durasi perjalanan 11 jam dengan mengujungi 4 daya tarik wisata, Orangutan University and Merabu Forest Tour dengan durasi 13 jam dan mengunjungi 4 daya tarik wisata, dan Mirror Lake and Whale Shark Tour dengan durasi 22 jam dengan mengunjungi 6 daya tarik wisata.

\section{Saran}

1. Biro Perjalanan Wisata yang ada di Kabupaten Berau harus terus berinovasi dalam membuat dan menjual paket wisata agar wisatawan tertarik untuk berkunjung.

2. Pemerintah setempat khususnya Dinas Pariwisata Kabupaten Berau sebaiknya terus melakukan promosi yang lebih banyak terhadap daya tarik wisata maupun paket wisata yang ada di Kabupaten Berau,

3. Masyarakat lokal sangat diharapkan untuk meningkatkan kesadaran terhadap potensi wisata yang ada dan terlibat langsung dalam pengelolaan daya tarik wisata di Kabupaten Berau, selalu menjaga kebersihan dan kelestarian daya tarik wisata yang memiliki potensi besar. 


\section{Kepustakaan}

Anonim. Undang-Undang No. 10 Tahun 2009 Tentang Kepariwisataan

Dewi, Susrami. 2016. "Paket Wisata Pedesaan "Become Pangsanian" di Desa Wisata Pangsan, Petang Badung". Denpasar. Universitas Udayana

Fandeli, et al. 2000. "Pengembangan Ekowisata dengan Paradigma baru pengelolaan areal konservasi". Di dalam: Fandeli C, Mukhclison, editor. Pengusahaan Ekowisata. Edisi I Yogyakarta: Fakultas Kehutanan, Univestias Gadjah Mada

Fiatiano, Edwin. 2016. "Perencanaan Paket Wisata atau Tur". Surabaya: Universitas Airlangga

Gantara, Helly. 2018. "Pengemasan Paket Ekowisata di Kabupaten Belitung Provinsi Bangka Belitung”. Denpasar. Universitas Udayana

Husni, Badri. 2019. "Studi Tentang Pengembangan Obyek Wisata Labuan Cermin di Kampung Biduk-Biduk Kecamatan Biduk-Biduk, Kabupaten Berau". Samarinda: Universitas Mulawarman

Mujiono, Kurniawan. 2019. "Identifikasi Potensi dan Ancaman Ecotourism Kecamatan Biduk-Biduk Kabupaten Berau Provinsi Kalimatan Timur". Samarinda: Universitas Mulawarman

Mulyadi, A.J. 2009. Kepariwisataan dan Perjalanan. Jakarta : Raja Grafindo Persada

Mulyani, Ani. 2016. "Perencanaan Paket Wisata berdasarkan Karakteristik dan Motivasi Wisatawan yang Datang ke Kampung Cirendeu, Kota Cimahi”. Bandung: Universitas Pendidikan Indonesia

Pendit, I Nyoman S. 1999. "Ilmu Pariwisata Sebuah Pengantar Perdana”. Jakarta: PT. Pradnya Paramita

Sugiyono, 2007. "Memahami Penelitian Kualitatif". Bandung: Alpabeta

Susilo, Heru. 2017. "Analisis Kebijakan untuk Pengembangan Ekowisata Berkelanjutan di Kawasan Perairan Labuan Cermin, Kabupaten Berau". Samarinda: Universitas Mulawarman
Suwena, I Ketut dan I Gst Ngr Widyatmaja. 2010. Pengetahuan Dasar Ilmu Pariwisata". Denpasar: Udayana University Press

Suyitno. 1999. "Pemandu Wisata (Tour Guiding). Yogyakarta : Kanisius

Suyitno. 1999. "Perencanaan Wisata. Yogyakarta : Kanisus

Swandewi, Luh Putu. 2014.”Perencanaan Paket Wisata Tirta di Kabupaten Buleleng". Denpasar: Fakultas Pariwisata Warman, Andri. 2020. "Kepariwisataan dan Perjalanan”. Samarinda: Gramedia 